\title{
ЗДІЙСНЕННЯ ПРАВА СВОБОДИ СВІТОГЛЯДУ ТА ВІРОСПОВІДАННЯ В ЦИВІЛЬНОМУ ПРАВІ УКРАЇНИ
}

\author{
БРИНЧАК Маріанна Петрівна - аспірант кафедри цивільного права та \\ процесу Харківського національного університету внутрішніх справ \\ https://orcid.org/0000-0003-2582-9897 \\ DOI:10.32782/EP.2020.2.21 \\ УДК 347.121.2(477)
}

\begin{abstract}
Статья посвящена исследованию осуществления личного неимущественного права свободъ мировоззрения и вероисповедания в Украине. В этой статье определено понятие общего осуществления свободъ мировоззрения и вероисповедания. Освещенъ основные тендениии осуществления и общие принципь свободъ мировоззрения и вероисповедания. Указано, как осуществляются личнъие неимущественнве права лица и какими правомочностями обладает бизическое лищо для осуществления своего права свободв мировоззрения и вероисповедания.

Ключевъие слова: свобода мировоззрения и вероисповедания, осуществление права, гражданское регулирования, правомочия, тенденизии осуществления.
\end{abstract}

Постановка проблеми: на сьогодні актуальним, але не достатньо розкритим $є$ питання здійснення свободи світогляду та віросповідання як одного з основоположних особистих немайнових прав людини.

\section{Стан дослідження проблеми}

3 огляду останніх вчень, виникла необхідність систематизації особистих немайнових прав, визначення їх поняття, форм, здійснення, способів захисту та змісту. Ці проблеми знайшли своє відображення у дослідженнях А.О. Красавчикової [1], М.Н. Малеїной [2], А.А. Анісімової і Н.В. Кальченка [3]. Накопичення до кінця першого десятиліття XXI століття емпіричного матеріалу, судової практики, в тому числі і міжнародної, поява окремих підходів до регулюванню особистих немайнових відносин не тільки різними правовими системами, але і в межах однієї системи, відкрило нові невирішені питання розуміння здійснення і захисту особистих немайнових прав. Ці проблеми частково розглядалися такими вченими, як Е.В. Кохановська [4], Р.О. Стефанчук [5], А.В. Федюк [6], А.В. Красицька [7], О. В. Синєгубов [8].

Метою і завданням статті є виділення i дослідження поняття здійснення права на свободу світогляду та віросповідання та як воно проявляється (дія, бездіяльність).

Виклад основного матеріалу

Кожна людина від народження наділена особистими немайновими правами, якими може користуватися в будь-який період свого життя. Одним з цих прав є свобода світогляду та віросповідання, яке набуло актуальності в умовах сучасної незалежної України. Як і інші особисті немайнові права особи, свобода світогляду та віросповідання закріплюється та регламентується Конституцією України, низкою міжнародних правових актів та іншими законами. За загальним правилом, під здійсненням права розуміють реалізацію тих можливостей, які надавалися законом або договором власнику суб'єктивного права. На даний момент постає питання щодо здійснення свободи світогляду та віросповідання в Україні. Це питання в минулому мало більш теоретич- 


\section{Цивільне, підприсмницьке, господарське та трудове право}

ний характер, та, враховуючи зміни, які відбуваються в Україні, проблемою є саме використання у практичній діяльності і це потребує більш детального теоретичного обгрунтування.

Історія розвитку людства свідчить про те, що знаходження людиною прав і свобод, розширення їх номенклатури завжди ставали ареною гострих зіткнень між індивідом і державою. Добровільно й активно надавати соціальні блага і політичні свободи держава не прагнула ніколи. Всі сучасні права людини, закріплені в міжнародних та національних документах, були вистраждані і відвойовані людством. Історія показує, що ця битва ще не закінчена, що новим поколінням потрібно знову і знову захищати свої права. Поки, на жаль, ще нереальна ситуація, при якій не буде вимагатися зусиль для підтримки і захисту прав і свобод людини. Повною мірою права можуть бути забезпечені і захищені у демократичній, соціальній, правовій державі [9]. В останні роки відбувається переосмислення базових людських цінностей включно з переглядом відносин людини і держави. Тому не випадковим є те, що реалізація права на свободу світогляду і віросповідання 6 важливим критерієм оцінки демократичності держави, а налагодження цивілізованих відносин з релігійними організаціями відіграє особливу роль в процесі розбудови молодої України. Останніми роками, насамперед, завдяки зусиллям певного кола політиків, юристів, інших наших співвітчзників питання захисту прав людини в Україні набуло загальносуспільного масштабу і політичного значення. Конституційний Суд України вважає, що право на свободу світогляду і віросповідання разом $з$ іншими фундаментальними правами і свободами є основою створення та функціонування демократичного суспільства. Всебічне утвердження і забезпечення цих прав і свобод - головний обов'язок України як демократичної, правової держави [10]. Стаття 1. Закону України «Про свободу совісті та релігійні організації» визначає основні завдання держави:

гарантування кожному можливості реалізації права на свободу віросповідання i світогляду, передбаченого Конституцією
України, незалежно від місця його перебування;

забезпечення рівності, захисту прав i законних інтересів кожної людини незалежно від ставлення до релігії;

закріплення принципів державної політики по відношенню до релігійних організацій та свободи віросповідання;

урегулювання стосунків між Церквою та Державою;

сприяння становленню традиційної Християнської Церкви як визначного культурного надбання та фактору етнічної спільності українського народу;

подолання негативних наслідків державної політики минулих часів щодо релігії та Церкви;

запобігання виникненню конфліктних ситуацій між релігійними організаціями, вирішення спірних міжцерковних питань на засадах законодавства України.

Стаття 3 вказаного вище Закону України дає таке тлумачення права на свободу совісті. «Кожному громадянину в Україні гарантується право на свободу совісті. Це право включає свободу мати, приймати і змінювати релігію або переконання за своїм вибором і свободу одноособово чи разом з іншими сповідувати будь-яку релігію або не сповідувати ніякої, відправляти релігійні культи, відкрито виражати і вільно поширювати свої релігійні або атеїстичні переконання.

Ніхто не може встановлювати обов'язкових переконань і світогляду. Не допускається будь-яке примушування при визначенні громадянином свого ставлення до релігії, до сповідання або відмови від сповідання релігії, до участі або неучасті в богослужіннях, релігійних обрядах і церемоніях, навчання релігії.

Батьки або особи, які ї замінюють, за взаємною згодою мають право виховувати своїх дітей відповідно до своїх власних переконань та ставлення до релігії.

Здійснення свободи сповідувати релігію або переконання підлягає лише тим обмеженням, які необхідні для охорони громадської безпеки та порядку, життя, здоров'я i моралi, а також прав і свобод інших громадян, встановлені законом і відповідають міжнародним зобов'язанням України» [11]. 
Виходячи із сучасних загальних закономірностей розвитку інституту основних прав ^юдини, є підстави говорити про наступні тенденції у здійсненні права на свободу віросповідання (віровизнання):

а) множинність вірувань - як результат урізноманітнення їх об'єктів. Вона відбувається внаслідок розвитку людської особистості, збагачення iї духовних потреб, розширення іï світогляду, обізнаності, змін уявлень. Ця тенденція чітко простежується і в Україні, про що свідчать нещодавні конкретно-соціологічні дослідження «стану релігійності» населення, зокрема молоді;

б) демонополізація ролі традиційних релігій у визначенні показників моральності, «праведності» способу життя та поведінки особи, життєдіяльності об'єднань, груп, спільнот, у встановленні критеріїв соціальне змістовного розмежування «добра» $\mathrm{i}$ «за» за конкретно-історичних умов, обставин. Одним із проявів цієї тенденції можна вважати посилення екуменічного (співпраця та взаєморозуміння між віросповіданнями різних конфесій) руху серед деяких церков. Симптоматичним $є$ також включення до складу тих моральних принципів, пропагувати які серед своїх прихильників погоджуються нині керівники певних церков, і такої чесноти, як віротерпимість (яку, зауважимо, слід тепер інтерпретувати як терпимість не лише до інших релігій, а й до атеїстів, до, так би мовити, «нерелігійно віруючих»);

в) деетнізація (втрата етнічних традицій) віри (зокрема, «віри релігійної»).

Особливо яскраво це спостерігається у процесах поширення нетрадиційних релігій, кількість прихильників яких збільшується серед представників різних етносів, серед жителів різних континентів, і Україна не $\epsilon$ винятком у цьому відношенні. Така тенденція не оминає і традиційні релігії (згадаймо, наприклад, рух «Евреї за Христа»). Ось чому дедалі рідше вживається поняття «національна релігія» (i, відповідно, поняття «національна церква»): адже до кожної конфесії належать люди різного етнічного походження, і це цілком нормальне явище. Навіть щодо України, де найпоширенішими є, як відомо, релігія православна (організаційно представлена кількома «центрами», інституціями) та греко-католицька, не можна, з цілком очевидних причин, вважати їх суто національними. У всіх зазначених тенденціях знаходить вияв закономірне розширення права людини на свободу віровизнання - процес, безумовно, прогресивний i гуманістичний. Він цілком відповідає принциповим засадам Загальної декларації прав людини 1948 р. (статті 18,19), Міжнародного пакту про громадянські і політичні права 1966 р. (статті 19,27), Декларації про права осіб, які належать до національних або етнічних, релігійних і мовних меншин 1992 р. (статті 2.1, 2.2, 4.2) [12].

Поняття здійснення свободи світогляду та віросповідання полягає у створенні або доповненні, в подальшому втіленні права свободи світогляду та віросповідання у діяльність цивільних суб'єктів прав шляхом дотримання меж, обмежень та заборон, використанні суб'єктивних прав і виконанні юридичних обов'язків.

Право свободи світогляду та віросповідання у цивільному праві здійснюється, як і інші цивільні особисті немайнові права. Загальне правило здійснення цивільних прав зазначено в Цивільному кодексі України у статті 12, де зазначено, що особа здійснює свої цивільні права вільно, на власний розсуд. Нездійснення особою своїх цивільних прав не $\varepsilon$ підставою для їх припинення, крім випадків, встановлених законом.

Цивільний кодекс України в статті 272 передбачає здійснення особистих немайнових прав, де зазначається, що фізична особа здійснює особисті немайнові права самостійно. В інтересах малолітніх, неповнолітніх, а також повнолітніх фізичних осіб, які за віком або за станом здоров'я не можуть самостійно здійснювати свої особисті немайнові права, їхні права здійснюють батьки (усиновлювачі), опікуни, піклувальники. Фізична особа має право вимагати від посадових і службових осіб вчинення відповідних дій, спрямованих на забезпечення здійснення нею особистих немайнових прав [13].

Ця стаття закріплює загальний порядок здійснення особистих немайнових прав, під час якого фізична особа, здійснюючи юридично значиму поведінку (дія, бездіяльність, рішення), безпосередньо або через інших 


\section{Цивільне, підприсмницьке, господарське та трудове право}

осіб, перетворює об'єктивно чинне право, у вигляді норми права, в право суб'єктивне, у вигляді створених правових можливостей. Окремі ж з особистих немайнових прав фізична особа здійснює з моменту народження без вчинення певної визначеної поведінки. Так, наприклад, право на свободу світогляду та віросповідання належить людині 3 моменту народження без вчинення певної визначеної поведінки. Специфіка здійснення особистих немайнового права свободи світогляду та віросповідання проявляється, насамперед, у їх правовій природі.

Так, право свободи світогляду та віросповідання, будучи тісно пов'язаним 3 особою носія, повинно здійснюватися нею самостійно, тобто вона сама вчиняе юридично значимі дії, які спрямовані на здійснення цього особистого немайнового права.

У коментарі до статті 272 Цивільного кодексу України зазначається також, що здійснення особистого немайнового права може передаватись іншим особам за окремих обставин, це стосується і права на свободу світогляду та віросповідання. Законодавець пов'язує таку можливість 3 недостатнім життєвим досвідом чи станом здоров'я, які не дозволяють фізичній особі самостійно здійснювати особисті немайнові права $з$ метою задоволення власних інтересів.

Саме тому законодавець визначає окремі випадки передачі можливості особистого немайнового права іншим особам 3 метою захисту цього права для носія фізичної особи. За загальним правилом існують такі випадки передачі можливості особистого немайнового права:

а) особисті немайнові права малолітніх осіб можуть здійснюватись їх батьками (усиновителями) та опікунами;

б) особисті немайнові права неповнолітніх осіб можуть здійснюватись їх батьками (усиновителями) та піклувальниками;

в) особисті немайнові права осіб, які визнані судом недієздатними, можуть здійснюватись їх опікунами;

г) особисті немайнові права повнолітніх осіб, які за віком чи станом здоров'я не можуть їх здійснювати і не визнані при цьому недієздатними, можуть здійснюватись їх піклувальниками.
Однак, слід зауважити, що така передача можливості щодо здійснення особистих немайнових прав іншими особами не тотожна поняттю їх передачі іншим особам [14].

Це означає, що передача особистих немайнових прав, а саме свободи світогляду та віросповідання взагалі неможлива, тому що вони тісно пов'язані з фізичною особою носієм. Окрім цього, здійснюючи особисте немайнове право шляхом вчинення юридично значимих діянь, зазначені особи створюють відповідні права та обов'язки не для себе, а для фізичних осіб - носіїв цих прав з метою задоволення їх інтересів.

На думку С.Т. Максименка, здійснення суб'єктивного цивільного права - це завершальний етап правового регулювання, i, як правило, в юридичній літературі саме таким чином абстрактна можливість (правоздатність) перетворюється спочатку в конкретну можливість (суб'єктивне право), а потім і в реальну дійсність (здійснення права) [15]. Таке визначення стосується всіх суб'єктів цивільних прав, особисті немайнові права не $є$ виключенням, тому що вони проходять всі ці стадії розвитку суб'єктивних цивільних прав.

Здійснення особистих немайнових прав засновується на можливих правомочностях. у Юридичній енциклопедії загальне визначення правомочності (лат. ius abutendi; також право розпорядження) - можливість власника речі (блага) визначати їі фактичну і юридичну долю [16]. Правомочність включає в себе право володіння і право користування, а також право вчинення фактичних дій.

Стефанчук Р.О. зазначав, що володіння особистим немайновим правом забезпечує особі автономне фізичне існування в реальному світі, а користування дозволяе пізнавати навколишнє середовище шляхом здійснення самостійної поведінки. Ці повноваження тісно пов'язані і не можуть існувати окремо одне від одного [17, с. 61-66].

Особисті немайнові права створюються спочатку у формі абстрактної можливості до правоволодіння, право в подальшому через систему встановлених у законі юридичних фактів набуває характеру відповідної конкретної можливості, яка, у свою чергу, дає 
підстави фізичній особі власною поведінкою здійснити вказані особисті немайнові права [18, с. 144-145].

Здійснення права свободи світогляду та віросповідання реалізується через можливість володіння цим правом 3 народження та можливість втілення цього права в життя, через конкретні норми (користуванням правом). Необхідно зазначити, що володіння та користування тісно пов'язані з особистістю особи і відсутність можливості володіти чи користуватися своїм правом свободи світогляду та віросповідання буде означати відсутність у людини цього права взагалі. Тому такі повноваження не можуть бути вилученими у фізичної особи жодним чином. Це буде суперечити об'єкту права свободи світогляду та віросповідання та можливості фізичного втілення.

Якщо це стосується особи, яка не досягла 14 років, весь спектр правомочностей щодо здійснення права дитини на розпорядження іiї свободою вибору світогляду та віросповідання повинен покладатися на ії батьків або осіб, що їх заміняють, 3 обов'язковим урахуванням іï інтересів, морального та психологічного розвитку, а також особистим бажанням дитини.

Реалізація права на свободу світогляду та віросповідання не повинна порушувати громадські, політичні, економічні, соціальні, духовні, екологічні та інші права, свободи і законні інтереси інших громадян, права та інтереси юридичних осіб.

Фізична особа як особистість має право на свободу вираження свого світогляду (поглядів щодо різних сфер суспільства та вільного формування цих поглядів), свобода світогляду та віросповідання не повинна формуватися в формах фізичного чи психічного, морального тиску на фізичну особу, це діє у випадках, коли світогляд та віросповідання цієї особи не завдає шкоди іншим особам.

Свобода світогляду та віросповідання дозволяє фізичній особі бути на рівних у демократичному суспільстві, впливає на іï самооцінку, вибір своєї поведінки, діянь, які засновуються саме на сформованому внутрішньому баченні світу, формуванню соціальної позиції, пріоритетів і переконань.
Правомочності свободи світогляду та віросповідання включають у себе:

- по-перше, можливість здійснювати власні юридично-значимі дії. Мати можливість на формування свого світогляду та вибору віросповідання, що включає в себе можливість фізичної особи бути носієм даного особистого немайнового блага (ознайомлення чи оприлюднення свого світогляду та віросповідання, визначаючи самостійно коло осіб, що можуть володіти такою інформацією про віру та погляди особи. Оприлюднення своїх поглядів та віросповідання може відбуватись не тільки особисто. Фізична особа може дати дозвіл на поширення свого світогляду іншими особами у визначених нею межах поширення, наприклад, через соціальні мережі Інтернет, шляхом SMS та MMS-повідомлень тощо. Обмежуються такі повноваження права свободи світогляду та віросповідання тільки у випадках, передбачених законом, які будуть суперечити інтересам національної безпеки, економічного добробуту та правам людини; фізична особа має можливість не розголошувати свій світогляд (погляди, ставлення та бачення) щодо різних суспільних сфер життя та обраного нею віросповідання (віри, атеїзму), а також вимагати такого нерозголошення від інших осіб, які володіють такою інформацією або можуть володіти);

- по-друге, повноваження на вільне, самостійне визначення свого світогляду та вибору віросповідання (віри).

Усі особисті немайнові права повинні здійснюватись без перешкод, у тих законодавчих межах, які будуть передбачені та закріплені чинним цивільним законодавством.

Суб'єкт особистих немайнових прав здійснюе право свободи світогляду та віросполвідання на основі загальних принципів здійснення особистих немайнових прав, а саме: здійснення особистих немайнових прав повинно відбуватись за системою принципів, яка носить складний трирівневий характер та містить у собі: 1) загальноправові (конституційні) принципи; 2) загальні цивільноправові принципи; 3) спеціальні принципи здійснення особистих немайнових прав. 


\section{Цивільне, підприємницьке, господарське та трудове право}

Свобода світогляду та віросповідання здійснюється через надані правомочності відповідно до меж та обмежень, які повинні бути окреслені законодавством. Здійснення свободи світогляду та віросповідання виходить із змісту самого права. Зміст особистого немайнового права свободи світогляду та віросповідання складається 3 повноважень до яких відносять можливість фізичної особи вільно, на власний розсуд визначати свою поведінку у сфері свого особистого (приватного) життя.

\section{Висновки}

Отже, здійснення суб'єктивного особистого немайнового права на свободу світогляду та віросповідання полягає в тому, що його носій може: використовувати його на свій розсуд без застосування будь-яких додаткових юридичних актів; вимагати від інших осіб припинення дій, спрямованих на обмеження його особистих немайнових прав; мати свободу поведінки, вчинків у межах, встановлених законом; звертатись до компетентних державних органів за захистом порушеного його особистого права, також особа володіє цим правом від народження, може ним користуватися у повному обсязі з певного віку.

\section{Література}

1. Красавчикова $\boldsymbol{\lambda}$. О. Понятие и система личных неимущественных прав граждан (физических лиц) в гражданском праве Pocсийской Федерации. Екатеринбург: Уральские военные вести, 1994. 200 с.; Она же. Понятие и система личных, не связанных с имущественными прав граждан (физических лиц) в гражданском праве Российской Федерации: автореф. дис. ... д-ра юрид. наук: 12.00.03. Урал. гос. юрид. акад. Екатеринбург, 1994. 43 с.

2. Малеина М. Н. Личные неимущественные права граждан: понятие, осуществление, защита. М.: М3 Пресс, 2000. 244 с.

3. Анисимов А. $\lambda$. Честь, достоинство, деловая репутация: гражданско-правовая защита. М.: Юристь, 1994. 80 с.; Кальченко Н. В. Право человека и гражданина на жизнь и его гарантии в Российской Федера- ции: дис. ... канд. юрид. наук: 12.00.03. Волгоград, 1995. 208 с.;

4. Кохановська О.В. Теоретичні проблеми інформаційних відносин у цивільному праві: монографія. Київ, 2006. 463 с.

5. Стефанчук Р. О. Особисті немайнові права фізичних осіб у цивільному праві (поняття, зміст, система, особливості здійснення та захисту): монографія. Київ: КНТ, 2008. $626 \mathrm{c}$.

6. Федюк ᄉ. В. Особисті немайнові права юридичних осіб: монографія. Івано-Франківськ, Прикарпатський нац. ун-т ім. Василя Стефаника, 2013. 500 с.

7. Красицька $\mathcal{\lambda . ~ В . ~ П р о б л е м и ~ з д і и ̆ с н е н н я ~}$ та захисту особистих та майнових прав батьків і дітей: монографія. Київ: Ліра-К, 2014. $628 \mathrm{c}$.

8. Синєгубов О. В. Здійснення особистих немайнових прав малолітніх та неповно літніх осіб: Монографія. Харків: Золота миля, 2015.528 c.

9.Способи захисту прав та свобод людини i громадянина. https:/studme.com. ua/195704114400/pravo/sposoby_zaschity_ prav_svobod_cheloveka_grazhdanina.htm

10. Рішення Конституційного Суду України у справі за конституційним поданням Уповноваженого Верховної Ради України 3 прав людини щодо відповідності Конституції України (конституційності) положень частини п'ятої статті 21 Закону України «Про свободу совісті та релігійні організації» (справа про завчасне сповіщення про проведення публічних богослужінь, релігійних обрядів, церемоній та процесій) від 8 вересня 2016 року № 6-pn/2016 (дата звернення 21.10.2019)

11. Закон України «Про свободу совісті та релігійні організації». Відомості Верховної Ради УРСР (ВВР), 1991, № 25, ст.283(дата звернення 21.10.2019)

12. Римаренко Ю.І. Приватне життя i поліція. Концептуальні підходи. Теорія та практика. Свобода світогляду і віросповідання. К.: КНТ, 2006. 740 с.

13. Цивільний кодекс України. Відомості Верховної Ради України (ВВР), 2003, №№ 40-44, ст.356 (дата звернення 21.10.2019) 


\section{АНОТАЦІЯ}

Стаття присвячена дослідженню здійснення особистого немайнового права свободи світогляду та віросповідання в Украӥні. У иій статті визначено поняття загального здійснення свободи світогляду та віросповідання. Висвітлено основні тенденцї здійснення та загальні принщипи свободи світогляду та віросповідання. Зазначено, як саме здійснюються особисті немайнові права особи та якими правомочностями наділена бізична особа для здіисснення свого права свободи світогляду та віросповідання.

Ключові слова: свобода світогляду та віросповідання, здійснення права, ицивілне регулювання, правомочності, тендениї здійснення.

14. Зміст і здійснення суб'єктивного цивільного права. http://osvita.ua/vnz/reports/ $\underline{\text { law } / 9676 /}$

15. С.Т. Максименко. Осуществление гражданских прав и исполнение обязанностей: Автореф. дис. юрид. наук.12.712 / Саратовский юрид. ин-т. Саратов , 1970. с.6-8

16. Право розпоряджання // Юридична енциклопедія : [у 6 т.] / ред. кол. Ю. С. Шемшученко (відп. ред.) [та ін.] К. : Українська енциклопедія ім. М. П. Бажана, 2003. Т. 5 : П С. 736 с. ISBN 966-7492-05-2.

17. Стефанчук Р. О. Право на здоров'я як особисте немайнове право фізичних осіб [Електронний ресурс] / Р. О. Стефанчук, А. М. Зелінський // Вісник Хмельницького інституту регіонального управління та права. 2003. - № 2. С. 61-66. Режим доступу: http://www.univer.km.ua/visnyk/494.pdf.

18. Стефанчук Р.О. Особисті немайнові права фізичних осіб (поняття, зміст, система, особливості здійснення та захисту): Монографія / відп. ред. Я.М. Шевченко. - К. КНТ, 2008. - 626 c. (c. 144-145)

\section{SUMMARY}

Realization of the right of freedom of outlook and religion in the civil law of Ukraine

The article is devoted to the research of the realization of personal non-property right of freedom of outlook and religion in Ukraine. This article defines the concept of a general realization of freedom of outlook and religion. The basic tendencies of realization and general principles of freedom of outlook and religion are exposed. It is stated how particularly personal nonproperty rights are realized and how exactly the individual is empowered to exercise his/her right of freedom of outlook and religion.

Every person from birth is endowed with personal non-proprietary rights that he or she can use at any time in his or her life. One of these rights is freedom of worldview and religion, which has become relevant in today's independent Ukraine.

As a general rule, the exercise of rights is understood as the realization of those opportunities which were provided by law or contract to the owner of the subjective right. At the moment, the question arises as to the exercise of freedom of thought and religion in Ukraine.

Based on the current general patterns of development of the institute of fundamental rights, there are reasons to speak about several basic trends in the exercise of the right to freedom of religion: a) multiple beliefs; b) demonopolizing of the role of traditional religions; c) the deethnization of faith.

This is clearly observed in the processes of the spread of non-traditional religions, the number of adherents of which is increasing among representatives of different ethnic groups, among residents of different continents, and Ukraine is no exception in this regard.

The right of having a freedom of thought and religion in civil law is exercised like other civil personal non-property rights.

The exercise of the subjective personal non-proprietary right to freedom of expression and religion is that its carrier may: use it at its discretion without the application of any additional legal acts; demand from other persons the termination of actions aimed at limiting his personal non-property rights; have freedom of conduct, act within the limits established by law; to apply to the competent state bodies for the protection of his violated personal right, also the person possesses this right from birth, can use it in full from a certain age.

Keywords: freedom of outlook and religion, realization of right, civil regulation, jurisdiction, tendencies of exercising. 